\title{
Typografische Konventionen
}

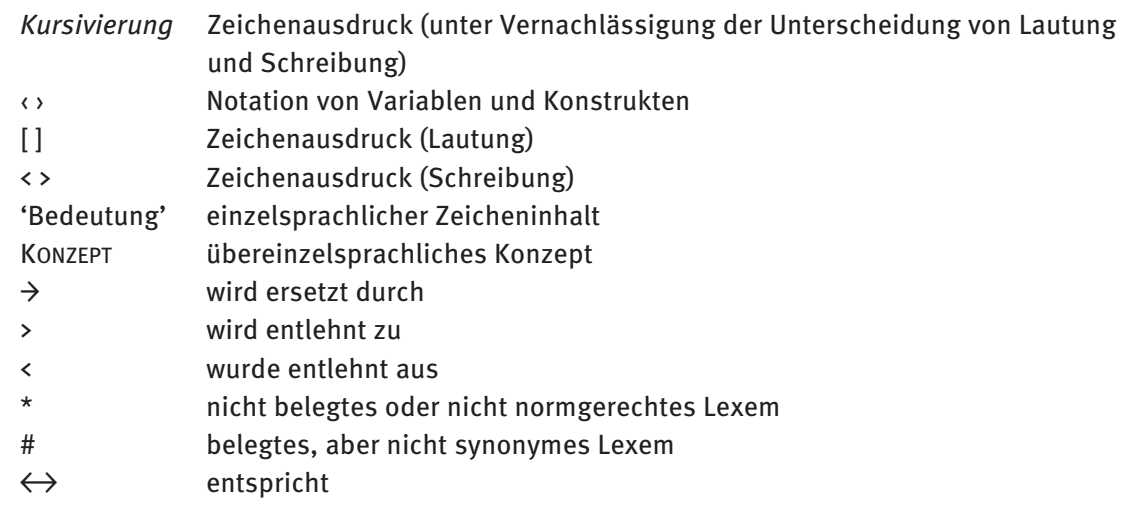


